\title{
CLINICAL CORRELATION OF NUTRIENT FORAMEN OF DRY HUMAN ULNA BONES IN JAMMU REGION
}

\author{
Kewal Kishore Thakur ${ }^{1}$, Rekha ${ }^{2}$, Simrit ${ }^{*}$, Simmi Thakur ${ }^{4}$, Sunanda Raina ${ }^{5}$. \\ ${ }^{1}$ Demonstrator, Department of Anatomy, Govt. Medical College Jammu, J \& K, India. \\ ${ }^{2}$ Demonstrator, Department of Anatomy, Govt. Medical College Jammu, J \& K, India. \\ ${ }^{*}$ Demonstrator, Department of Anatomy, Govt. Medical College Jammu, J \& K, India. \\ ${ }^{4}$ Medical Officer, Health Department, Jammu, J \& K, India. \\ ${ }^{5}$ Professor and HOD, Department of Anatomy Govt. Medical College Jammu, J \& K, India.

\section{ABSTRACT}

\begin{abstract}
Background: The nutrient foramen of Human ulna bone is on the anterior surface of shaft of ulna almost proximal to the mid point and is directed upwards. Nutrient foramen permits the passage of the branch of anterior
\end{abstract} interosseous artery.

Methods: The present study was conducted on 70 dry human ulna bones of unknown sex and age obtained from Government Medical College Jammu. The Ulna bones were observed macroscopically for nutrient foramen.

Results: In our study we observed that only 2 bones were without nutrient foramen and two of the bones with two nutrient foramen on right side while one foramen on all the left side. The location of nutrient foramen in right and left ulna bones was $72 \%$ in the middle one third, $18 \%$ in upper third and $8 \%$ at the junction of upper and middle one third. The position of nutrient foramen was $80 \%$ on the anterior surface, $11 \%$ on the Interosseous border and $7 \%$ on the anterior border. All the foramen were directed upwards

Conclusion: The study of nutrient foramen is of utmost importance to the forensic experts as in determining the length of ulna and to the orthopaedicians for deciding different treatment modalities in case of fractures of shaft of ulna so as to prevent non-union or avascular necrosis and also helpful for highly specialised surgical procedures like vascularised bone grafting involving microsurgery.

KEY WORDS: Nutrient Foramen, Ulna, anterior interosseous artery..

Address for Correspondence: Dr Simriti, Demonstrator, Department of Anatomy, Govt. Medical college Jammu, Jammu and Kashmir, India. Contact No: +919419113524, +919419787722.

E-Mail: simritibias20@gmail.com

Access this Article online

Quick Response code

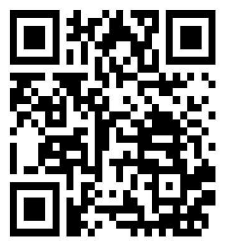

DOI: $10.16965 /$ ijar.2018.342

Journal Information

International Journal of Anatomy and Research

ICV for 2016
$\mathbf{9 0 . 3 0}$ $\begin{gathered}\text { ISSN (E) 2321-4287 I ISSN (P) 2321-8967 } \\ \text { https://www.ijmhr.org/ijar.htm } \\ \text { DOI-Prefix: https://dx.doi.org/10.16965/ijar }\end{gathered}$

Article Information

Received: 04 Aug 2018

Peer Review: 06 Aug 2018

Revised: None
Accepted: 06 Sep 2018

Published (O): 10 Oct 2018

Published (P): 10 Oct 2018

\section{INTRODUCTION}

Long bones get their nutrition from nutrient artery through nutrient foramen (NF) as the name itself signifies. The nutrient foramen of human ulna bone is on the anterior surface of shaft of ulna, almost proximal to its midpoint which is directed upwards and permits the branch of anterior interosseous artery [1].

Hence lower end is the growing end of the bone, in consistent with the general rule that towards the elbow I go, from the knee I flee. This is because one end of limb bone grows faster than the other do [2].

Most of the long bones have at least one NF, 
sometimes double and occasionally none. The position is described as somewhat in the middle of the shaft [3]. It was suggested that the pull of muscle attachments on the periosteum explained certain anomalous nutrient foramina directions [4]. Nutrient artery can be in surgical danger in cases of isolated ulnar shaft fractures (though rare but can happen while trying to fend off a blow leading to delay in fracture union).

Nutrient artery to ulna is a branch of anterior interosseous artery. The role of nutrient foramen in growth and nutrition of long bones is very important and is evident from the term 'nutrient' itself. The knowledge of position of nutrient foramen is important from medico legal aspect, as well as surgical point of view. In medico legal practice, the knowledge of nutrient foramen can help us to calculate total length of bone, if one knows the ratio between the total length of bone and the distance of nutrient foramen from both ends of the bone. This is helpful in cases if a piece of bone is found having both ends broken, but nutrient foramen is present in the bone. Similarly height of the individual can be reconstructed. The direction of nutrient foramen of all long bones is away from growing ends. The knowledge of position of nutrient foramen in long bones is also helpful in certain surgical procedures, such as joint replacement therapy, fracture repair, bone graft and vascularised bone microsurgery[5].

The position and direction of nutrient foramen are known to vary in human long bones [6]. Nutrient arteries, the main blood supply to the long bones are positively important during active growth period as well as during early phases of ossification [7]. Long bones receive about $80 \%$ of its blood supply from nutrient arteries[8]. Nonsurgical treatment of isolated ulnar shaft fractures (IUSF) is prone to complications and is associated with malunion and nonunion. This presumably is due to vascular interruption [9]. One of the causes of delayed union or non-union of fracture is lack of arterial supply [10].Two well-known factors may affect nutrient foramen position. These are growth rates at two ends of the shaft and bone remodelling[11]. In longitudinal stress fractures, the position of nutrient foramen and pattern of edema of forearm may be usefull [12].

\section{MATERIALS AND METHODS}

In present study 70 human ulna bones of unknown sex and age were studied. They were 35 of right and 35 of left side and labelled as ' $L$ ' for left and ' $R$ ' for right sided ulna bones. The measurements were taken with the help of Vernier calliper. The parameters noted were:

1. Number of nutrient foramen.

2. Location of nutrient foramen.

3. Position of nutrient foramen.

4. Distance of nutrient foramen from upper end, measured as the distance from most proximal point on olecranon process upto nutrient foramen.

5. Distance of nutrient foramen from lower end, measured as the distance from the tip of styloid process upto nutrient foramen.

Table 1: Number of Nutrient Foramen.

\begin{tabular}{|c|c|c|c|c|}
\hline \multirow{2}{*}{$\begin{array}{c}\text { Ulna } \\
\text { Bones }\end{array}$} & \multirow{2}{*}{ No. } & \multicolumn{3}{|c|}{ Number of Nutrient Foramen } \\
\cline { 3 - 5 } & & Zero & One & Two \\
\hline Right & 35 & 2 & 31 & 2 \\
\hline Left & 35 & 0 & 35 & 0 \\
\hline Total & 70 & 2 & 66 & 2 \\
\hline
\end{tabular}

Table 1 shows that number of nutrient foramen is different in both right and left ulna bones, out of 35 right bones 2 bones were without foramen, 2 bones were with 2 nutrient foramen and 31 bones were with 1 foramen, while all 35 left ulna bones have one nutrient foramen each.

Table 2: Location of Nutrient Foramen in Right, left and total ulna bones.

\begin{tabular}{|c|c|c|c|c|c|}
\hline \multirow{2}{*}{$\begin{array}{c}\text { Ulna } \\
\text { Bones }\end{array}$} & \multirow{2}{*}{ No. } & \multicolumn{5}{|c|}{ Location of Nutrient foramen } \\
\cline { 3 - 6 } & & $\begin{array}{c}\text { Upper } \\
1 / 3^{\text {rd }}\end{array}$ & $\begin{array}{c}\text { Junction of upper } 1 / 3^{\text {rd }} \\
\text { and middle } 1 / 3^{\text {rd }}\end{array}$ & $\begin{array}{c}\text { Middle } \\
1 / 3^{\text {rd }}\end{array}$ & $\begin{array}{c}\text { Lower } \\
1 / 3^{\text {rd }}\end{array}$ \\
\hline Right & 35 & 8 & 2 & 25 & 0 \\
\hline Left & 35 & 5 & 4 & 26 & 0 \\
\hline Total & 70 & 13 & 6 & 51 & 0 \\
\hline
\end{tabular}

Table 2 shows the location of nutrient foramen in both right and left ulna bones, out of 35 right bones 25 nutrient foramen are present in middle $1 / \beta^{\text {rd }}, 8$ are present in upper $1 \beta^{\text {rd }}$ and 2 in junction of upper $1 \beta^{\text {rd }}$ and middle $1 / \beta^{\text {rd }}$ and no nutrient foramen is observed in lower $1 / 3^{\text {rd }}$ portion.In 35 left Ulna bones, 26 are present in middle $1 / 3^{\text {rd }}$ portion, 5 are present in upper $1 / 3^{\text {rd }}$ portion, 4 are present in the junction of upper $1 / \beta^{\text {rd }}$ and middle $1 \beta^{\text {rd }}$ portion. No nutrient foramen is observed in lower $1 / 3^{\text {rd }}$ portion. 
Table 3: Position of nutrient foramen in right, left and total ulna bones.

\begin{tabular}{|c|c|c|c|c|}
\hline \multirow{2}{*}{$\begin{array}{c}\text { Ulna } \\
\text { Bones }\end{array}$} & \multirow{2}{*}{ No. } & \multicolumn{3}{|c|}{ Position of Nutrient foramen } \\
\cline { 3 - 5 } & & $\begin{array}{c}\text { Anterior } \\
\text { surface(AS) }\end{array}$ & $\begin{array}{c}\text { Interosseous } \\
\text { Border(IB) }\end{array}$ & $\begin{array}{c}\text { Anterior } \\
\text { Border(AB) }\end{array}$ \\
\hline Right & 35 & 30 & 1 & 4 \\
\hline Left & 35 & 27 & 4 & 4 \\
\hline Total & 70 & 57 & 5 & 8 \\
\hline
\end{tabular}

Table 3 shows position of nutrient foramen in right, left and total ulna bones. In 35 right bones, 30 nutrient foramen are positioned in anterior surface, 4 nutrient foramen are positioned in anterior border and 1 nutrient foramen is positioned in interosseous border. In 35 left ulna bones, 27 nutrient foramen are positioned in anterior surface, while 4 nutrient foramen each are positioned in anterior border and interosseous border.

Table 4: Mean Distance of nutrient foramen from upper end of right, left and total ulna bones.

\begin{tabular}{|c|c|c|c|}
\hline \multirow{2}{*}{ Ulna Bones } & \multirow{2}{*}{ No. } & \multicolumn{2}{|c|}{$\begin{array}{c}\text { Distance of Nutrient foramen } \\
\text { from upper end }\end{array}$} \\
\cline { 3 - 4 } & & Mean \pm SD(mm) & Range $(\mathrm{mm})$ \\
\hline Right & 35 & $97.37 \pm 16.26$ & $63-127$ \\
\hline Left & 35 & $96.82 \pm 11.93$ & $76-127$ \\
\hline Total & 70 & $97.1 \pm 14.10$ & $63-127$ \\
\hline
\end{tabular}

The statistical analysis of mean distance of nutrient foramen from upper end in right, left and total ulna bones as shown in Table 4. Mean distance of nutrient foramen from upper end in right and left ulna bones is $97.37(\mathrm{SD} \pm 16.26) \mathrm{mm}$ and $96.82(\mathrm{SD} \pm 11.93) \mathrm{mm}$ respectively. Mean distance of nutrient foramen from upper end in total bones is (97.1 SD \pm 14.10 ) $\mathrm{mm}$. Mean distance of nutrient foramen from upper end in right ulna bones is slightly more than in left ulna bones.

Table 5: Mean Distance of nutrient foramen from Lower end of right, left and total ulna bones.

\begin{tabular}{|c|c|c|c|}
\hline \multirow{2}{*}{$\begin{array}{c}\text { Ulna } \\
\text { Bones }\end{array}$} & \multirow{2}{*}{ No. } & $\begin{array}{r}\text { Distance of Nutrient foramen from } \\
\text { lower end }\end{array}$ \\
\cline { 3 - 4 } & & Mean \pm SD (mm) & Range (mm) \\
\hline Right & 35 & $164.71 \pm 14.06$ & $136-198$ \\
\hline Left & 35 & $163.34 \pm 19.80$ & $124-222$ \\
\hline Total & 70 & $164.02 \pm 16.93$ & $124-222$ \\
\hline
\end{tabular}

Table 5 illustrates the statistcal analysis of the mean distance of nutrient foramen from lower end in right, left and total ulna bones. Mean distance of nutrient foramen from lower end in right and left ulna bones is 164.71 (SD \pm 14.06$)$ $\mathrm{mm}$ and 163.34 (SD \pm 19.80$) \mathrm{mm}$ respectively. Mean distance of nutrient foramen from lower end in total bones is (164.02 SD \pm 16.93$) \mathrm{mm}$. Mean distance of nutrient foramen from lower end in right ulna bones is more than in left ulna bones.

\section{DISCUSSION}

The role of nutrient foramen in growth and nutrition of long bones is very important. Hence, thorough knowledge of position and direction of nutrient foarmen is important from medicolegal aspect as well as in orthopaedics and plastic surgery. In medicolegal practice the knowledge of nutrient foramen helps us to correlate the total length of bone, whereas in orthopaedics its role is in fracture treatment [4]. Knowledge of foramen is very useful in surgical procedure to preserve circulation, especially to orthopaedic surgeon to perform open reduction of fractures and bone graft surgeries [13].

In the present study, the maximum number of bones show only one nutrient foramen, which is in agreement with the results of the previous studies. Out of 70 bones 2 bones of right side of ulna were having two foramen whereas 2 bones were having no foramen. Rest 31 right ulna bones each were having single foramen. All the left ulna bones showed single foramen. The incidence of double nutrient foramen is in consonance with Chattarpati and Mishra [14], who observed 3 bones with double nutrient foramen out of 68 ulna bones studied. However, Longia et al [15] observed 8 bones with double nutrient foramen, out of 200 bones studied. Kizilkanat et al [7] conducted their study on 102 ulna bones and observed only one bone with double foramen and no bone having zero foramen. Anusha and Naidu [8] conducted their study on 50 ulna bones and observed that all the ulna bones were having single nutrient foramen.

In the present study out of 70 bones,location of maximum number of nutrient foramen were observed in middle $1 / 3^{\text {rd }}$ that is $51(73 \%)$ while in upper $1 / 3^{\text {rd }}$ there were $13(18.5 \%)$ and at the junction of upper and middle $1 / 3^{\text {rd }} 6(8.5 \%)$ of the foramen observed. The finding of present study are in accordance with findings of Mysoreker[6], who observed that out of 188 ulna 
foramen, 117 (62\%) were present in middle one third, 66 (35\%) in upper third and five (3\%) at the junction of upper and middle third. Our findings are in consistence with Anusha and Naidu [8] who reported that out of 50 foramen 29 (58\%) were present on the upper one third, and $21(42 \%)$ on the middle third.

The finding of our study are in accordance with Chattarpati and Mishra [14] who reported 80\% foramen present on the anterior surface similarly in present study maximum number (82\%) of foramen were present on anterior surface.

The findings of present study concerning distance of nutrient foramen from upper and lower ends are in accordance with the study of Chattarpati and Mishra[14] who found distance from upper end on right side approximately $94.6 \mathrm{~mm}$ and on the left side $98.1 \mathrm{~mm}$. the distance from lower end on right and left side were $161.96 \mathrm{~mm}$ and $157.52 \mathrm{~mm}$ respectively whereas Anusha and Naidu[8] documented the distance from upper end approximately $98.5 \mathrm{~mm}$ and distance from lower end about $173.20 \mathrm{~mm}$.

\section{CONCLUSION}

This study provides importance about morphology and topography of nutrient foramina. The study of nutrient foramen is of utmost importance to the forensic experts as in determining the length of ulna and to the orthopaedicians for deciding different treatment modalities in cases of fracture of shaft of ulna so as to prevent non-union or avascular necrosis and also helpful for surgical procedures, such as joint replacement therapy, bone graft and vascularised bone microsurgery.

\section{Conflicts of Interests: None}

\section{REFERENCES}

[1]. Standring S. Gray's Anatomy. The Anatomical Basis Of Clinical Practice, $40^{\text {th }}$ edition. Churchill Livingstone (Elsevier)2005: 844.

[2]. Henderson RG, The position of the nutrient foramen in the growing tibia and femur of the rat, J Anat, 1978 125(Pt 3):593-599.

[3]. Hughes $\mathrm{H}$. The factors determining the direction of the canal for the nutrient artery in the long bones of mammals and birds. Acta Anat (Basel). 1952; 15:261-280.

[4]. Lacroix P. The organization of bones. London: J. \& A. Churchill, 1951.

[5]. Malukar $\mathrm{O}$ and Joshi H. Diaphyseal nutrient foramen in long bones and miniature long bones.NLIRM2011;2(2):23-26.

[6]. Mysorekar VR. Diaphyseal nutrient foramina in Human Long bones.J Anat1967;101(4):813-822.

[7]. Kizilkalat E, BoyanN,OzsahinET, SoamesR and OgusO. LocationAnn Anatomy 2007; 189(1):87-95.

[8]. Anusha P and Naidu MP. A study on the nutrient foramina of long bones.J Med Sci Tech 2013;2(3):150-157.

[9]. Thomas W Wright, Frank Glowczewskie. Vascular anatomy of the ulna. J Hand Surg. 1998;23(5):800804).

[10]. Turek SL. Orthopaedics, principles \& their application. Philadelphia and Montreal: J. B. Lippincott Company, 2004. pp 59-60).

[11]. Henderson RG. The position of the nutrient foramen in the growing tibia and femur of the rat. J Anat. 1978; 125:593-599.

[12]. Craig JG, Widman D and Van Holsbeeck M. Longitudinal stess fracture: patterns of edema and the importance of nutrient foramen. Skeleton Radiol 2003; 32(1):22-27.

[13]. Gupta R, Singh AK, Kumar R. Morphological study of nutrient foramina in human fibulae of north India Region. Int J Med Health Sci 2013 (April);vol2, issue2.

[14]. Chattarpati DN and Mishra BD. Position of Nutrient foramen, on the shaft of human long bone. JAnat Soc Ind 1967; 16: 54-63.

[15]. Longia GS,Ajmani ML,Saxena SK and Thmas RJ. Study of Diaphyseal Nutrient Foramina in Human long bones. Acta Anat (Basel) 1980; 107 (4): 399-406.

How to cite this article:

Kewal Kishore Thakur, Rekha, Simrit, Simmi Thakur, Sunanda

Raina. CLINICAL CORRELATION OF NUTRIENT FORAMEN OF DRY

HUMAN ULNA BONES IN JAMMU REGION. Int J Anat Res 2018;6(4.1):5788-5791. DOI: 10.16965/ijar.2018.342 